\title{
Expression studies in the embryo and in the micropylar endosperm of germinating coffee (Coffea arabica cv. Rubi) seeds
}

\author{
E. T. de Farias $\cdot$ E. A. Amaral da Silva $\cdot$ \\ Peter E. Toorop $\cdot$ J. Derek Bewley $\cdot$ \\ Henk W. M. Hilhorst
}

Received: 16 January 2014 / Accepted: 16 July 2014/ Published online: 3 August 2014

(C) The Author(s) 2014. This article is published with open access at Springerlink.com

\begin{abstract}
Germination of coffee (Coffea arabica L.) seed is slow and uneven. Its germination is the net result of events that occur simultaneously in the embryo and endosperm and which are controlled by abscisic acid (ABA). The aim of the study was to monitor the expression of genes related to the cell cycle and to cell wall modifications, including an actin $(A C T)$, a cyclin-dependent kinase $(C D K 2 a)$ and $\alpha$-expansin $(\alpha$-EXP) in the embryo, and $\alpha$ galactosidase $(\alpha-G A L), \beta$-mannosidase (LeMSIDE2), endo$\beta$-mannanase (MANA) in the micropylar endosperm. The first seed germinated after 5 days of imbibition and $50 \%$ germination was reached after 10 days. The embryo grew inside the seed prior to radicle protrusion and ABA inhibited both embryo growth and radicle protrusion. The expression of the genes associated with the embryo growth increased during germination and ABA partially inhibited expression. The expression of $\beta$-mannosidase and endo- $\beta$ mannanase increased during imbibition and ABA completely inhibited expression of these genes. However, $\alpha$ -
\end{abstract}

E. T. de Farias · E. A. A. da Silva $(\bowtie)$

Departamento de Produção e Melhoramento Vegetal, Faculdade de Ciências Agronômicas-UNESP, Universidade Estadual Paulista, Botucatu, SP 18.610-307, Brazil

e-mail: amaraldasilva@fca.unesp.br

P. E. Toorop

Seed Conservation Department, Royal Botanic Gardens Kew, Wakehurst Place, Ardingly, West Sussex RH17 6TN, UK

\section{J. D. Bewley}

Department of Molecular and Cellular Biology,

University of Guelph, Guelph, Canada

H. W. M. Hilhorst

Laboratory of Plant Physiology, Wageningen University,

Droevendaalsesteeg 1, 6708 PB Wageningen, The Netherlands galactosidase displayed a more constitutive expression and was less affected by ABA. ABA plays a dual role in the regulation of coffee seed germination; it concomitantly controls both endosperm weakening and embryo growth.

Keywords Abscisic acid - Cell cycle - Cell wall · Embryo growth $\cdot$ Endosperm weakening

\section{Introduction}

Coffee belongs to the Rubiaceae family and C. arabica is the species with the greatest economic importance, and is responsible for $70 \%$ of the volume of coffee traded in the world. Coffee is considered one of the major commodities and Brazil is the largest producer, accounting for $25 \%$ of the world production. The germination potential of the coffee seed is an important aspect of the coffee production chain, both during processing of the coffee berries and in producing seedlings for new crop. Various molecular techniques, as well as the sequenced coffee genome (Vieira et al. 2006) can be used to investigate genes associated with germination in coffee seeds that may function as markers to monitor seed quality.

The coffee embryo is surrounded by endosperm tissue (Krug and Carvalho 1939; Mendes 1941). The endosperm cells possess thick cell walls, which are largely composed of mannan-rich polymers with $2 \%$ of galactose (Wolfrom et al. 1961; Bewley et al. 2012). Three enzymes have been suggested to be involved in the hydrolysis of the cell wall mannans: $(1 \rightarrow 4)-\beta$-mannan endohydrolase (EC 3.2.1.78; referred to here as endo- $\beta$-mannanase), $\beta$-mannosidase (EC 3.2.1.25) and $\alpha$-galactosidase (EC 3.2.1.22).

The micropylar endosperm cap of the coffee seed, opposing the radicle tip, is weakened during germination and endo- $\beta$-mannanase activity increases before the first 
seed of the batch shows radicle protrusion (da Silva et al. 2004). Tissue printing showed occurrence of endo- $\beta$ mannanase activity, initially in the endosperm cap surrounding the radicle tip, and only later, during germination, in the rest of the endosperm (da Silva et al. 2004). Three different isoforms of this enzyme were found in the endosperm cap during germination and another isoform was detected in the rest of the endosperm later during germination. Marraccini et al. (2001) have demonstrated that whole coffee seeds contain 8 different isoforms of endo- $\beta$-mannanase, following germination. The same authors isolated two different cDNA clones of endo- $\beta$ mannanase from germinated coffee seeds (MANA and $M A N B$ ), which suggests that these different isoforms are at least partly caused by post-transcriptional modifications. The enzyme $\beta$-mannosidase cleaves the oligomeric mannose products resulting from endo- $\beta$-mannanase activity (Bewley et al. 2012) and has been found and characterized in seeds of several species (McCleary 1982; McCleary and Matheson 1975). It is likely to be present during coffee seed germination but to date this has not been confirmed.

In addition to the events that occur in the endosperm during coffee seed germination, the coffee embryo grows inside the seed prior to radicle protrusion, by cell expansion and elongation. These events take place concomitantly with DNA synthesis and accumulation of the protein $\beta$ tubulin (da Silva et al. 2008) and an increase in embryo pressure potential (da Silva et al. 2004).

Abscisic acid (ABA) inhibits radicle protrusion in coffee seed by exerting its effect both in the embryo and the endosperm (da Silva et al. 2004, 2008). In the embryo ABA inhibits the accumulation of $\beta$-tubulin, as well as growth and cell division of the embryo, the alignment of microtubules and nuclear DNA replication, and the increase in embryo pressure potential (da Silva et al. 2004, 2008). In the micropylar endosperm, ABA inhibits the second step of endosperm cap weakening and the occurrence of two isoforms of endo- $\beta$-mannanase.

Although, these results contribute to the understanding of the mechanism and regulation of coffee seed germination, there is little known about the underlying transcriptional changes in embryo and micropylar endosperm and possible regulation by $\mathrm{ABA}$.

\section{Materials and methods}

Seed material

Coffee fruits at the cherry stage (C. arabica L. cv. Catuaí Amarelo) were harvested in Machado-MG-Brazil, depulped mechanically, wet fermented for $24 \mathrm{~h}$, dried to $12 \%$ moisture content and stored at $10{ }^{\circ} \mathrm{C}$ until use.
Germination conditions

The surrounding seed coat was removed by hand and four repetitions of 25 seeds were surface sterilized in $1 \%$ sodium hypoclorite for $5 \mathrm{~min}$ and then rinsed in water. The seeds were placed between paper towels in 90-mm Petri dishes and imbibed in $10 \mathrm{ml}$ demineralized water or 1,000 $\mu \mathrm{M}$ ABA (Sigma, St. Louis MO, USA). The seeds were kept at $30 \pm 1{ }^{\circ} \mathrm{C}$ in the dark and germination was scored daily as visible radicle protrusion of $>1 \mathrm{~mm}$ (da Silva et al. 2004; Huxley 1965; Valio 1976). ABA solution was prepared with $\mathrm{KOH}$ followed by neutralization in $1 \mathrm{~N}$ $\mathrm{HCl}$ (da Silva et al. 2004).

\section{Embryo growth}

Ten embryos from water- and ABA-imbibed seeds were dissected from the seeds by cutting the endosperm with a razor blade. The embryos were measured with the use of digital calipers. After that the embryos were dissected in hypocotyls and cotyledons and measured again.

\section{RNA extraction and cDNA synthesis}

Three biological replicates of 50 embryos and 50 micropylar endosperms were dissected from seeds imbibed in water or $1,000 \mu \mathrm{M}$ ABA. Embryos and micropylar endosperms were frozen in liquid nitrogen and ground to a powder with the aid of mortar and pestle in the presence of liquid nitrogen and stored at $-80^{\circ} \mathrm{C}$. Total RNA extraction was performed using the commercial NucleoSpin RNA Plant $^{\circledR}$ kit (Macherey-Nagel, Bethlehem PA, USA). Approximately $100 \mathrm{mg}$ of the ground powder was added to $350 \mu \mathrm{l}$ of the extraction buffer and $3.5 \mu \mathrm{l}$ of $\beta$-mercaptoethanol and homogenized by vortexing. The extracted RNA was quantified in a Nanodrop-2000 spectrophotometer (Thermo Scientific, Wilmington DE, USA). RNA integrity was confirmed in a $1 \%$ agarose gel. cDNA synthesis was performed with the commercial kit ProtoScript ${ }^{\circledR}$ (New England Biolabs, Ipswich MA, USA) using RNA from micropylar endosperms and embryos from seeds imbibed in water or in ABA for 1, 3, 6 and 9 days. For each biological sample 1,000 ng of total RNA, $5 \mu \mathrm{M}$ of d(T)23 primers plus $6 \mu \mathrm{M}$ of random primers and nuclease free water were used. The samples were incubated at $70{ }^{\circ} \mathrm{C}$ for $5 \mathrm{~min}$ and dipped on ice. Following, $10 \mu \mathrm{l}$ of AMV Reaction Mix ${ }^{\circledR}$ and $2 \mu \mathrm{l}$ of AMV Enzyme Mix ${ }^{\circledR}$ were added. The samples were placed in a thermocycler at a temperature of $25{ }^{\circ} \mathrm{C}$ for $5 \mathrm{~min}$, at $42{ }^{\circ} \mathrm{C}$ for $1 \mathrm{~h}$ and at $80{ }^{\circ} \mathrm{C}$ for $5 \mathrm{~min}$ for inactivation of the enzymes. The cDNA was quantified in a Nanodrop-2000 spectrophotometer (Thermo Scientific, Wilmington DE, USA). 
Table 1 Genes (mRNAs) studied during coffee seed germination in embryo and micropylar endosperm

\begin{tabular}{llll}
\hline $\begin{array}{l}\text { Gene } \\
\text { symbol }\end{array}$ & Gene name & Related to & References \\
\hline $\begin{array}{l}A C T \\
C D K 2 a\end{array}$ & $\begin{array}{l}\text { Actin } \\
\text { Cyclin- } \\
\text { dependent } \\
\text { kinase }\end{array}$ & $\begin{array}{c}\text { Cytoskeleton } \\
\text { Cell cycle }\end{array}$ & $\begin{array}{c}\text { Gilliland et al. (2003) } \\
\text { Valedez-Gonzálex } \\
\text { et al. (2007) }\end{array}$ \\
$\alpha$-EXP & $\alpha$-Expansin & $\begin{array}{c}\text { Cell } \\
\text { expansion }\end{array}$ & $\begin{array}{c}\text { Chen and Bradford } \\
(2000)\end{array}$ \\
$\alpha-G A L$ & $\alpha$-Galactosidase & $\begin{array}{c}\text { Cell wall } \\
\text { degradation }\end{array}$ & $\begin{array}{c}\text { Zhu and Goldstein } \\
(1994)\end{array}$ \\
MANA & $\begin{array}{c}\text { Endo- } \beta \text { - } \\
\text { mannanse }\end{array}$ & $\begin{array}{c}\text { Cell wall } \\
\text { degradation }\end{array}$ & $\begin{array}{c}\text { Mo and Bewley } \\
(2002)\end{array}$ \\
MSIDE & $\beta$-Mannosidase & $\begin{array}{c}\text { Cell wall } \\
\text { degradation }\end{array}$ & $\begin{array}{c}\text { Marraccini et al. } \\
(2001)\end{array}$ \\
& & &
\end{tabular}

Primer design

Gene-specific primers were designed from cDNA of ACTIN (SGN-U618902), CYCLIN-DEPENDENT KINASE (SGNU607600) and ALPHA-EXPANSIN (GQ434002.1) that were available from the Sol Genomics Network database (http://solgenomics.net/about/about_solanaceae.pl). Sequences of cDNA of ALPHA-GALACTOSIDASE (L27992.1) and ENDO-BETA-MANNANASE (AJ293305) were available from the NCBI database (http://www.ncbi.nlm.nih.gov/). The amino acid sequence of BETA-MANNOSIDASE (da Silva 2002), was used for design of its primers. The amino acid sequence was converted into a nucleotide sequence by using the tool of the European Bioinformatics Institute (http:// www.ebi.ac.uk/Tools/st/emboss_backtranseq/). Sequences were then submitted to Primerquest (http://biotools.idtdna. com/Scitools/Applications/Primerquest/), for final primer design (Tables 1, 2).

Expression studies

Real-Time PCR was performed using an Eco Real-Time(Illumina) with gene specific primers, cDNA and EvaGreen ${ }^{\circledR}$ master mix. For each reaction we used $1 \mu \mathrm{l}$ of cDNA (100 ng), $0.4 \mu \mathrm{l}$ of forward and reverse primers at a concentration of $2.0 \mu \mathrm{M}$ and $10 \mu \mathrm{l}$ of Master Mix EvaGreen ${ }^{\circledR}$ for a final volume of $20.0 \mu \mathrm{l} / \mathrm{sample}$. The amplification protocol consisted of $2 \mathrm{~min}$ at $50{ }^{\circ} \mathrm{C}, 10 \mathrm{~min}$ at $95^{\circ} \mathrm{C}$; then 40 cycles of $10 \mathrm{~s}$ at $95{ }^{\circ} \mathrm{C}$ and $30 \mathrm{~s}$ at $61{ }^{\circ} \mathrm{C}$. Melting curves were determined to assess specificity. The universal $18 \mathrm{~S}$ primer was used as internal control to normalize the products. Real-time PCR was performed three times using biological replicates. Values of fold chance in gene expression were calculated in relation to 1 day of imbibition, using $2^{-\Delta \Delta \mathrm{Ct}}$, and plotted.

Statistical analysis

Data was subjected to ANOVA and the averages were compared using the Tukey test at $5 \%$ probability level.

\section{Results}

\section{Germination}

The first seeds showed radicle protrusion at 5 days from the start of imbibition and $50 \%$ of the seed population showed radicle protrusion after 10 days. Germination of the whole population was completed at day 15 of imbibition (Fig. 1), confirming previous observations that coffee seed exhibits relatively slow and variable radicle protrusion. For seeds imbibed in 1,000 $\mu \mathrm{M}$ ABA germination was completely inhibited (Fig. 1). In a previous study we have shown that only this relatively high concentration is effective, likely because of low penetration or internal binding of ABA (da Silva et al. 2004).

\section{Embryo growth}

The coffee embryo grew prior to radicle protrusion in water-imbibing seeds. There was a significant increase in length from day 1 to day 9 of imbibition in the whole embryo, as well as in the hypocotyl and in the cotyledons $(P<0.05)$. When $50 \%$ of the seeds showed radicle protrusion, at day 10 of imbibition, the average length of the embryos, hypocotyls, and cotyledons was 5.02, 3.20, and
Table 2 Specific primers for coffee embryo and micropylar endosperm cap used in real time PCR

\begin{tabular}{lll}
\hline Name & Forward & Reverse \\
\hline$A C T$ & TTGGCTCCCAGCAGCATGAA & TGCTGGAATGTGCTGAGGGA \\
$C D K 2 a$ & TTTGGATTGGCCCGTGCCTT & AGCCAACTGACCACACGTCA \\
$\alpha-E X P$ & TCGTGCAGGCATCGGTCAAA & AAGAGCGACGGTCACTTGCT \\
$\alpha-G A L$ & TCCATGGACGGTGCGACTTT & AAGAGGTCCAGCCCAAACCT \\
$M S I D E$ & TTGGGCCGTGAAGTCGTGAA & AAGGCAGCAACCACTCTTGG \\
$M A N A$ & TCCTGGATACCAAGTGGGCA & AACATCATCTGTGCACCGTCGC \\
$18 S$ & TGACGGAGAATTAGGGTTCG & CCTCCAATGATCCTCGTTA
\end{tabular}




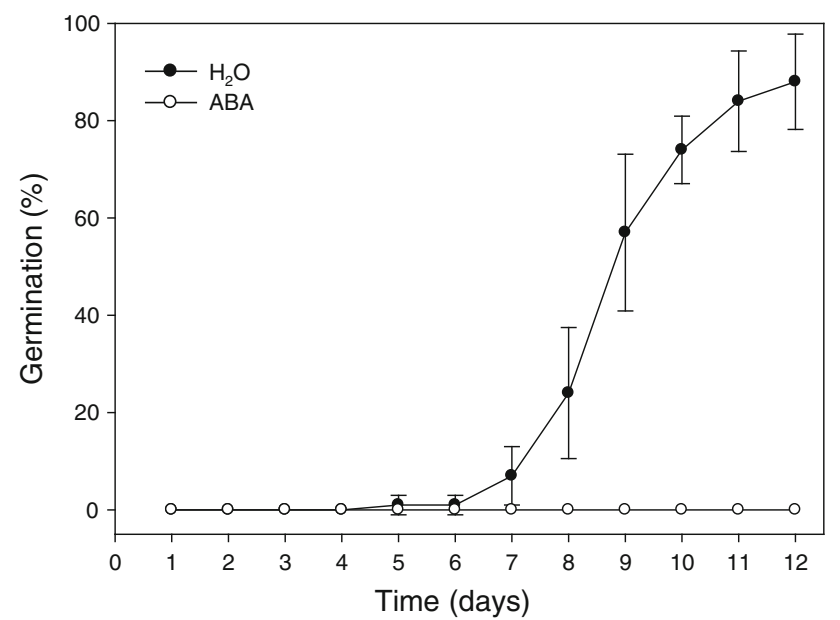

Fig. 1 Germination of coffee seeds in water (filled circle) and in ABA $(1,000 \mu \mathrm{M})$ (open circle). Data points are average of 4 replicates of 25 seeds each. Error bars indicate standard deviation

$1.82 \mathrm{~mm}$, respectively (Fig. 2). When coffee seeds were imbibed in ABA there was no significant increase in length of embryo, hypocotyl, or cotyledons (Fig. 2). The length of the embryo remained around $4.01 \mathrm{~mm}$ during the whole imbibition period. The length of the hypocotyl was $2.48 \mathrm{~mm}$ and of the cotyledons $1.53 \mathrm{~mm}$. Comparing the length of embryo, hypocotyl and cotyledons from waterimbibed seeds with ABA-imbibed seeds there was a significant difference in length in embryo and hypocotyl. No significant difference was found for cotyledon length in water- and ABA-imbibed seeds (Fig. 2).

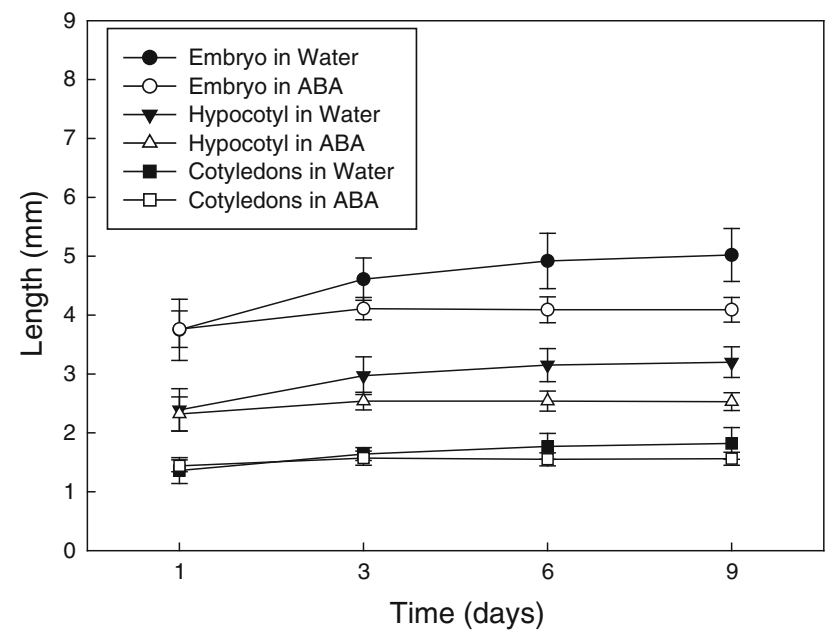

Fig. 2 Embryo length in water (filled circle), and ABA (open circle) hypocotyl length in water (filled triangle) and ABA (open triangle) and cotyledons length in water (filled square) and $\mathrm{ABA}$ (open square) of coffee seeds imbibed in water and 1,000 $\mu \mathrm{M}$ ABA. Data points are average of 10 embryos and error bars indicate standard deviation. The difference in embryo and hypocotyl length between water- and ABA imbibed seeds were significant at the level of $(P<0.05)$

\section{Gene expression}

The reference gene used for the normalization of the expression values showed no significant difference in threshold cycle $(\mathrm{Ct})$ of the embryonic genes for water- and ABA imbibed seeds. The $\mathrm{Ct}$ varied from 16.35 to 17.01 for water-imbibed seeds and from 16.35 to 17.87 for ABAimbibed seeds (Fig. 3a, b).

The expression of embryonic $A C T$ showed a significant increase during germination in water. For ABA-imbibed seeds there was also a significant increase but it was less pronounced. Comparing water- and ABA-imbibed seeds the expression of $A C T$ in water was always significantly superior to that in ABA (Fig. 4a).

$C D K 2 a$ expression increased during imbibition in water but this was only significant after 9 days of imbibition. For ABA-imbibed seeds a significant decrease in the expression of $C D K 2 a$ was observed between 3 and 6 days and leveling off thereafter. Comparing water- and ABA-
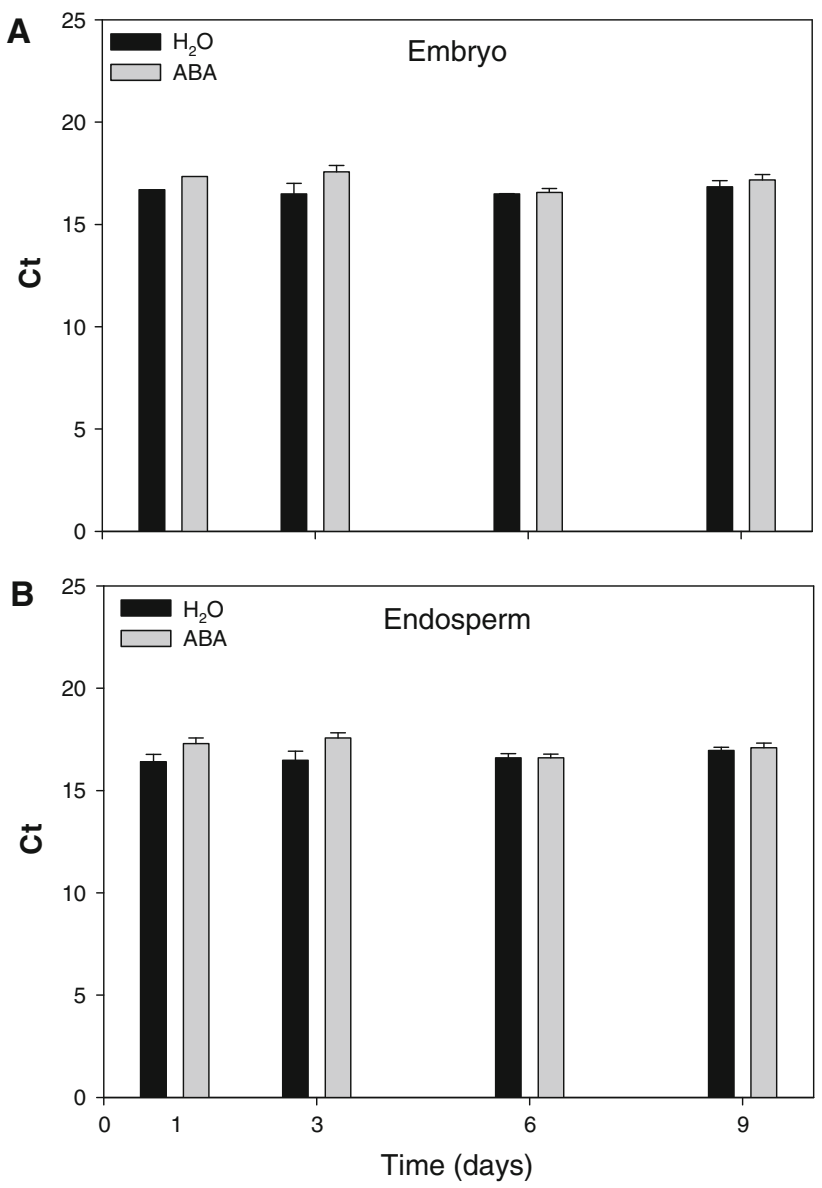

Fig. $3 \mathrm{Ct}$ of the $18 \mathrm{~S}$ gene from the embryo (a) and from the micropylar endosperm (b) of coffee seeds imbibed in water and in ABA $(1,000 \mu \mathrm{M})$. The error bars indicate standard deviation of three biological replications 

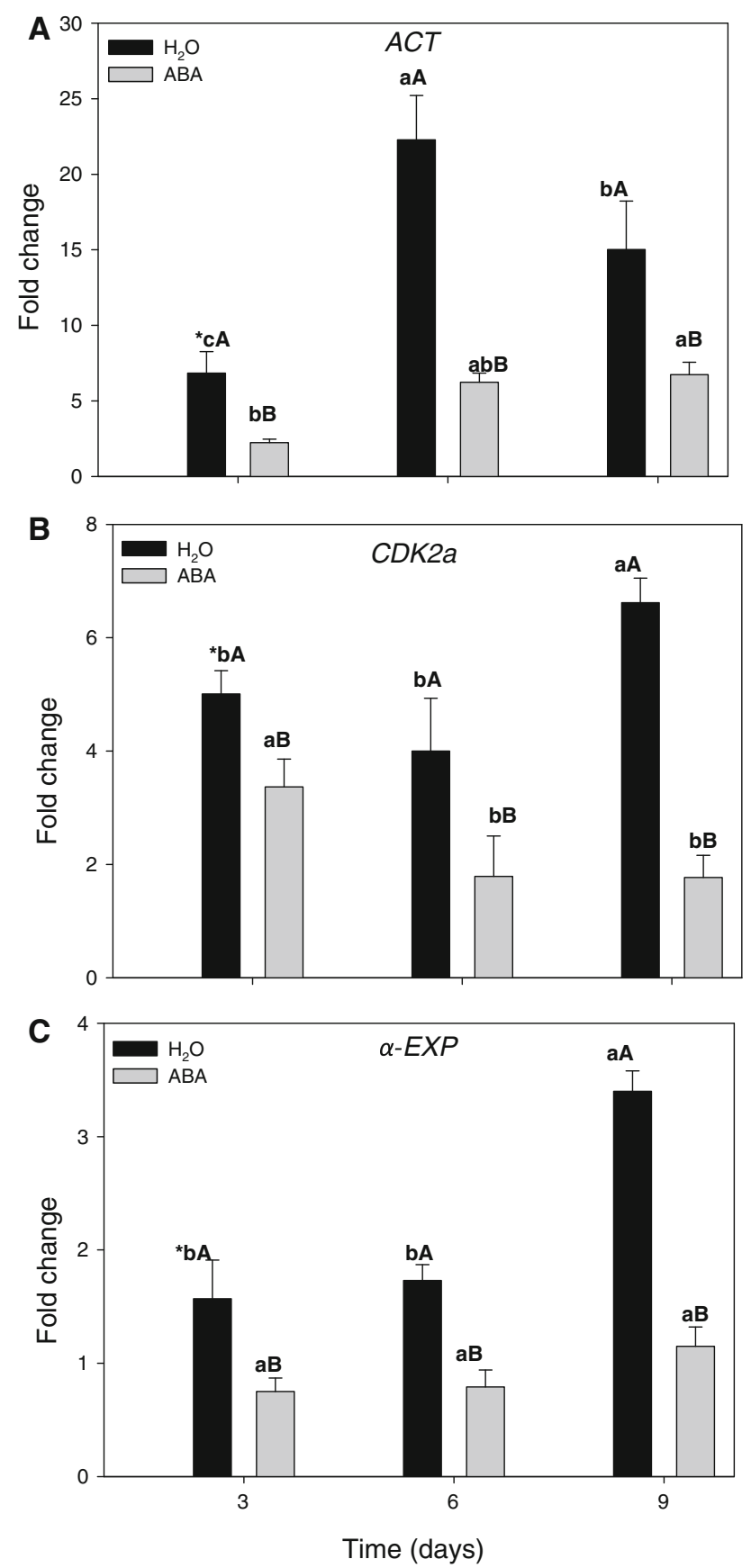

Fig. 4 Relative fold change in transcript abundance of $A C T$ (a), $C D K 2 a(\mathbf{b})$ and $\alpha-E X P(\mathbf{c})$ in embryos of seeds imbibed in water or in ABA $(1,000 \mu \mathrm{M})$. The error bars indicate standard deviation of three biological replications. Averages followed by the same lower-case letter within the treatments (water or $\mathrm{ABA}$ ) and capital letter between the treatments (water and ABA) do not differ by the Tukey test at the level of $5 \%$ probability

imbibed seeds $C D K 2 a$ expression was always lower in the ABA-treated embryos (Fig. 4b).

The abundance of $\alpha-E X P$ transcripts increased prior to radicle protrusion in water-imbibed seeds. However, only after 9 days of imbibition this increase was significant. For
ABA-imbibed seeds the transcripts kept at a constant level during imbibition and no significant differences could be detected. Comparing the transcript abundance between water- and $\mathrm{ABA}$ imbibed seeds there was a significant difference between these treatments, where water imbibed seeds always showed higher levels of $\alpha$-EXP expression (Fig. 4c).

The expression of $\alpha-G A L$ in the micropylar endosperm from water-imbibed seeds did not change until 6 days of imbibition after which a slight increase was observed at day 9. For ABA-imbibed seeds no significant change in $\alpha$ GAL transcript abundance could be observed during imbibition. However, comparing water and ABA-imbibed seeds there was a significant difference in transcript level at day 6 and 9 of imbibition (Fig. 5a).

Transcript abundance of MSIDE increased approximately eightfold between 3 and 9 days of imbibition in water. However, in ABA-imbibed seeds the expression of $M S I D E$ was inhibited. Comparing water- and ABA imbibed seeds there was a significant difference during imbibition but a profound increase was only observed after 6 and 9 days of imbibition in water (Fig. 5b).

The MANA transcript abundance in the micropylar endosperm displayed a steep and significant increase between 3 and 9 days of imbibition whereas ABA almost completely inhibited accumulation of MANA transcripts (Fig. 5c).

\section{Discussion}

The coffee embryo grew inside the seed prior to radicle protrusion, which confirms our previous observations (da Silva et al. 2004). These events take place concomitantly with DNA synthesis and accumulation of $\beta$-tubulin (da Silva et al. 2008) and an increase in embryo pressure potential (da Silva et al. 2004). Here we showed that gene expression of $\alpha$-expansin, a cell-wall associated protein, increased during imbibition and prior to radicle protrusion. Expansins may contribute to the disruption of hydrogen bonds between cell wall components (Bewley et al. 2012), allowing cell expansion and growth during coffee seed germination.

Actin is part of the cell cytoskeleton (Gilliland et al. 2003). Arrays of actin filaments are associated with plant cell growth, and the activity of actin-binding proteins is essential for cell morphogenesis (Hussey et al. 2006). Another protein, $\beta$-tubulin, is also part of the microtubular machinery and it was previously shown to increase in the coffee embryo during cell elongation prior to and after germination, changing its random orientation to a more transverse orientation (da Silva et al. 2008). Thus, the occurrence and increase of actin transcript abundance and 

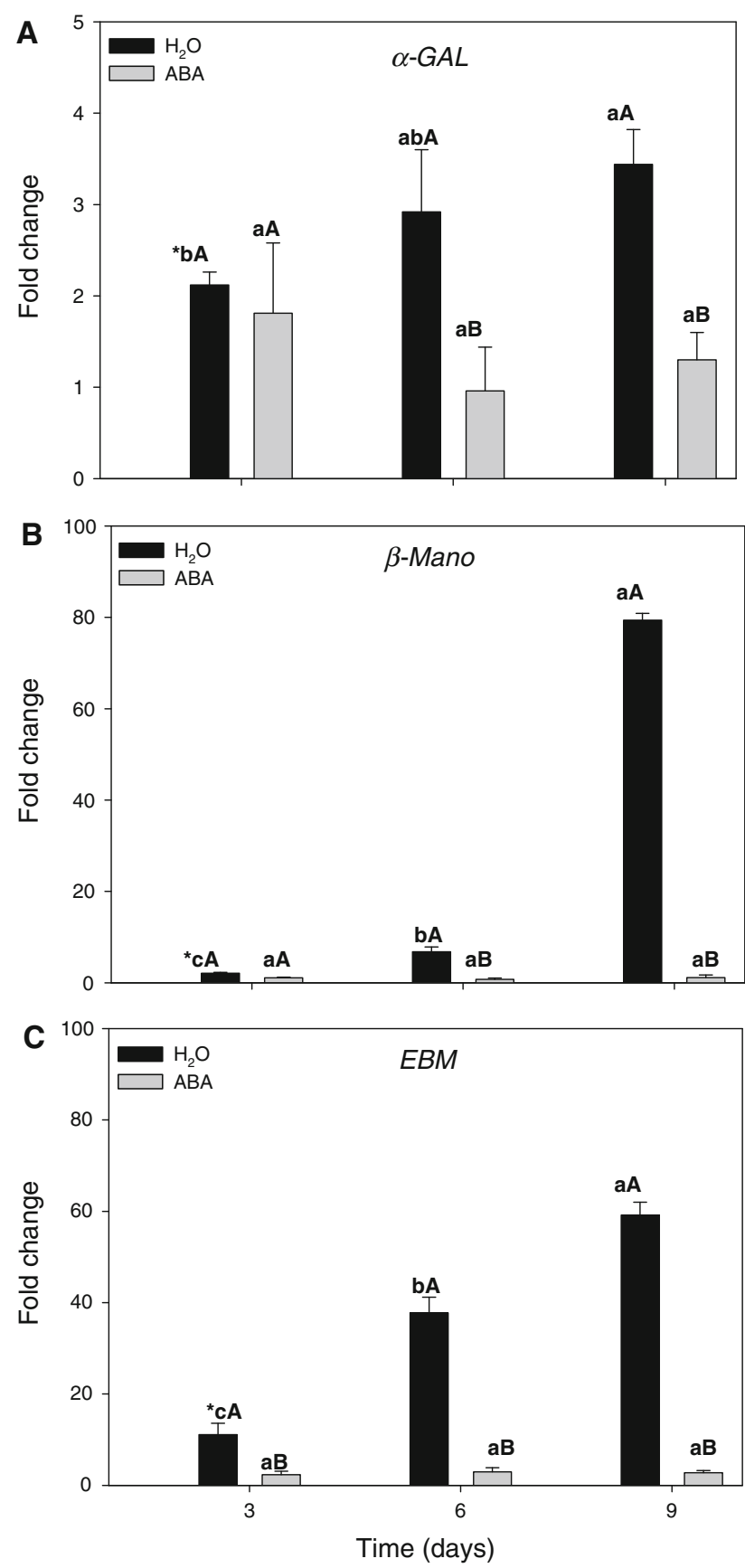

Fig. 5 Relative fold change in transcript abundance of $\alpha-G A L$ (a), LeMside 2 (b) and ManA (c) in the micropylar endosperm of seeds imbibed in water or in $\mathrm{ABA}(1,000 \mu \mathrm{M})$. The error bars indicate standard deviation of three biological replications. Averages followed by the same lower-case letter within the treatments (water or ABA) and capital letter between the treatments (water and $\mathrm{ABA}$ ) do not differ by the Tukey test at the level of $5 \%$ probability

accumulation of the $\beta$-tubulin protein point at their importance in coffee embryo growth by contributing to cell expansion.

Most of the known cyclin-CDK complexes regulate progression through the cell cycle (Godínez-Palma et al.
2013). However, in the coffee embryo cell division is an event that only takes place after radicle protrusion (da Silva et al. 2008). Thus, it seems that the here observed increase of $C D K 2 a$ expression during imbibition must be considered as a preparation for cell division after radicle protrusion.

Coffee endosperm cell walls are composed mainly of mannans with $2 \%$ of galactose present in the side chain (Bewley et al. 2012; Wolfrom et al. 1961). The cells in the coffee endosperm cap have thinner cell walls than the cells of the rest of the endosperm (da Silva et al. 2004), which indicates that the region in the endosperm where the radicle will protrude is predestined. However, it does not exclude the requirement of endosperm cap weakening to facilitate radicle protrusion. Expression of MANA, a gene encoding an endo enzyme involved in the degradation of the mannan backbone (Bewley 1997), increased mainly in the micropylar endosperm before completion of germination of the first seed. In addition, quantification and tissue printing has shown that endo- $\beta$-mannanase activity appeared first in the micropylar endosperm and only later in the rest of the endosperm (da Silva et al. 2004). MSIDE, the gene encoding $\beta$-mannosidase, an enzyme that hydrolyses the oligomeric mannose products resulting from endo- $\beta$-mannanase activity, displayed increased expression in the micropylar endosperm prior to radicle protrusion, following the same trend as MANA (Fig. 3).

Thus, increased expression of the encoding genes, as well as activities of endo- $\beta$-mannanase and $\beta$-mannosidase in the micropylar endosperm, prior to radicle protrusion, appear to be involved in the germination process i.e. weakening of the endosperm cap. Evidently, endo- $\beta$-mannanase is the first enzyme in the hydrolysis of the mannan backbone and is likely to be the main enzyme involved in endosperm cap weakening in coffee whereas $\beta$-mannosidase hydrolyzes the oligomeric mannose products resulting from endo- $\beta$-mannanase activity (Bewley et al. 2012).

Thus, since germination in coffee seed is the net result of endosperm weakening and embryo growth (da Silva et al. 2004), we may conclude that endo- $\beta$-mannanase and $\beta$-mannosidase genes play an important role during coffee seed germination by mediating weakening of the endosperm cap. The weakening of the micropylar endosperm makes it less resistant to the embryonic radicle puncturing through the endosperm cap cell walls.

The coffee embryo displayed a transient increase in endogenous ABA during germination and imbibition of the seeds in fluridone, an inhibitor of carotenoid biosynthesis, promoted the advancement of seed germination by 1 day (da Silva et al. 2004). Here we show that exogenous ABA leads to inhibition of embryo growth and radicle protrusion. Concomitantly, ABA significantly inhibited the increase of the expression of embryonic $C D K 2 a, \alpha-E X P$ and $A C T$ during imbibition. Taken together, these results 
suggest a dual role for ABA in the regulation of coffee seed germination, directed both at embryo and endosperm.

Acknowledgments We thank CAPES (Fundação e Aperfeiçoamento de Pessoal de Nível Superior) for financial support of the studies of E. T. de Farias. The seed lab at Lavras Federal UniversityMG-Brazil (UFLA) is acknowledged by the gift of the coffee seeds.

Open Access This article is distributed under the terms of the Creative Commons Attribution License which permits any use, distribution, and reproduction in any medium, provided the original author(s) and the source are credited.

\section{References}

Bewley JD (1997) Breaking down the walls-a role for endo- $\beta$ mannanase in release from seed dormancy? Trends Plant Sci 2:464-469

Bewley JD, Bradford KJ, Hilhorst HWM, Nonogaki H (2012) Seeds. Physiology of development, germination and dormancy. Springer, New York

Chen F, Bradford KJ (2000) Expression of an expansin is associated with endosperm weakening during tomato seed germination. Plant Physiol 124:1265-1274

da Silva EAA (2002) Coffee (Coffea arabica cv. Rubi) seed germination: mechanism and regulation. Dissertation, Wageningen University

da Silva EAA, Toorop EP, van Aelst AC, Hilhorst HWM (2004) Abscisic acid controls embryo growth potential and endosperm cap weakening during coffee (Coffea arabica cv. Rub) seed germination. Planta 220:251-261

da Silva EAA, Toorop PE, van Lammeren AAM, Hilhorst HWM (2008) ABA inhibits embryo cell expansion and early cell division events during coffee (Coffea arabica 'Rubi') seed germination. Ann Bot 102:425-433

Gilliland LU, Pawloski LC, Kandasamy MK, Meagher RB (2003) Arabidopsis actin gene ACT7 plays an essential role in germination and root growth. Plant J 33:319-328
Godínez-Palma SK, García E, de la Paz Sánchez M, Rosas F, Vazquez-Ramos JM (2013) Complexes of D-type cyclins with CDKs during maize germination. J Exp Bot 64:5661-5671

Hussey PJ, Ketelaar T, Deeks MJ (2006) Control of the actin cytoskeleton in plant cell growth. Annu Rev Plant Biol 57:109-125

Huxley PA (1965) Coffee germination test recommendations and defective seed types. Proc Int Seed Test Ass 30:705-715

Krug CA, Carvalho A (1939) Genetical proof of the existence of coffee endosperm. Nature 144:515

Marraccini P, Rogers WJ, Allard C (2001) Molecular and biochemical characterization of endo- $\beta$-mannanase from germinating coffee (Coffea arabica) grains. Planta 213:296-308

McCleary BV (1982) Purification and properties of mannosidase mannohydrolase from guar. Carbohydr Res 101:75-92

McCleary BV, Matheson NK (1975) Galactomannan structure and endo- $\beta$-mannanase and $\beta$-mannosidase activity in germinating legume seeds. Phytochemistry 14:1187-1194

Mendes AJT (1941) Cytological observations in coffee. VI. Embryo and endosperm development in Coffea arabica L. Am J Bot 28:784-789

Mo B, Bewley JD (2002) $\beta$-Mannosidase (E.C.3.2.1.25) activity during and following germination of tomato (Lycopersicon esculentum Mill.) seeds. Purification, cloning and characterization. Planta 215:141-152

Valedez-Gonzálex N, Colli-Mull JG et al (2007) Differential effect of aluminum on DNA synthesis and CDKA activity in two Coffea arabica cell line. J Plant Growth Regul 26:69-77

Valio IFM (1976) Germination of coffee seeds (Coffea arabica L. cv. Mundo Novo). J Exp Bot 27:983-991

Vieira LGE, Andrade AC, Colombo CA (2006) Brazilian coffee genome project: an EST-based genomic resource. Rev Bras Fisiol Veg 18:95-108

Wolfrom ML, Laver ML, Patin DL (1961) Carbohydrates of coffee bean II. Isolation and characterization of a mannan. J Org Chem 26:4533-4536

Zhu A, Goldstein J (1994) Cloning and functional expression of a cDNA encoding coffee bean $\alpha$-galactosidase. Gene 140:227-231 